\title{
Implementasi Iptek untuk Standardisasi, Pemasaran, dan Distribusi Produk Kerajinan Sulaman Kain Karawo bagi Usaha Mikro, Kecil, dan Menengah (UMKM) di Kabupaten Gorontalo
}

\author{
Ismet Sulila ${ }^{1}$, Tineke Wolok ${ }^{2}$, Abdul Rahman Pakaya ${ }^{3}$ \\ 1, 2,3 Universitas Negeri Gorontalo
}

\begin{tabular}{ll} 
Article History & ABSTRACT \\
\hline Received 07.02.2019 & THE IMPLEMENTATION OF IPTEK (SCIENCE AND TECHNOLOGY) OF \\
Received in revised form & PRODUCT STANDARDIZATION, MARKETING, AND DISTRIBUTION OF \\
Accepted 01.04.2019 & KARAWO FABRIC EMBROIDERY CRAFTS AT GROUP OF MICRO, SMALL, \\
Available online 30.04.2019 & AND MEDIUM ENTERPRISES OF GORONTALO DISTRICT. Community service \\
through a development program of Karawo embroidery as the regional \\
competitive product was conducted in Religious Tourism Village of Bongo in \\
Gorontalo District. The program was focused on a gradual and measurable \\
concrete effort in improving Community Economic Empowerment. Specific targets \\
that should be achieved through the program were product standardization, \\
marketing, and distribution. In implementing the program, it is necessary to have \\
a method which is able to achieve the targeted results. Thus, the applied approach \\
method was unique and different which encompassed: 1) determination of the \\
solved problem priority scale, 2) doing reconstruction and improvement gradually, \\
3) improvement based on local community character approach, 4) implementation \\
of science and technology. Based on the study of the implementation of science and \\
technology, the result showed that: 1) the implementation of science and \\
technology of Karawo product standardization could give a limit of product \\
quality based on market need, price, and product users. 2) The implementation of \\
science and technology of marketing through the use of social media could improve \\
market demand for the varied product of Karawo in local and national level. 3) The \\
implementation of science and technology of distribution of varied product to \\
consumers performed through online media and transportation could distribute \\
varied product to the consumers. Overall, it was concluded that the \\
implementation of science and technology by university/ college had given real \\
contribution to the effort of improvement of empowerment and welfare of the \\
community.
\end{tabular}

Keywords: Distribution, Iptek, Marketing, Product Standardization, UMKM. 


\section{PENDAHULUAN}

Karawo adalah kain tradisional khas Gorontalo yang pembuatannya merupakan hasil kerajinan tangan. Tak ada kain Karawo yang bukan hasil kerajinan tangan. Karawo merupakan bahasa Gorontalo yang artinya Sulaman tangan. Orang-orang diluar Gorontalo mengenalnya dengan sebutan Karawo. Karawo lahir dari proses panjang yang merupakan buah dari ketekunan para perajin. Seni membuat Karawo atau Karawo disebut "MoKarawo". Seni ini telah diturunkan dari generasi ke generasi sejak masa kerajaan Gorontalo masih berjaya. Keindahan motif, keunikan cara pengerjaan dan kualitas yang bagus membuat Karawo bernilai ekonomi sangat tinggi. Maka tak mengherankan jika keunikan dan kualitas tersebut diminati oleh banyak kalangan baik dari dalam maupun luar negeri.

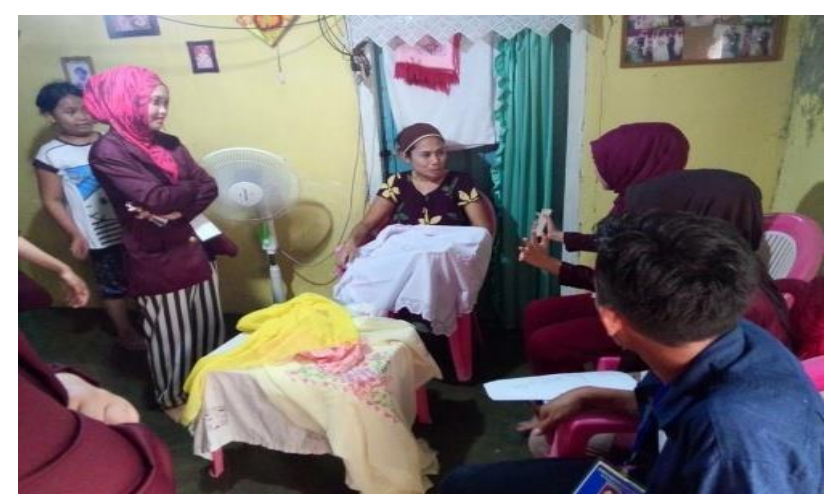

Gambar 1. Observasi produk Karawo

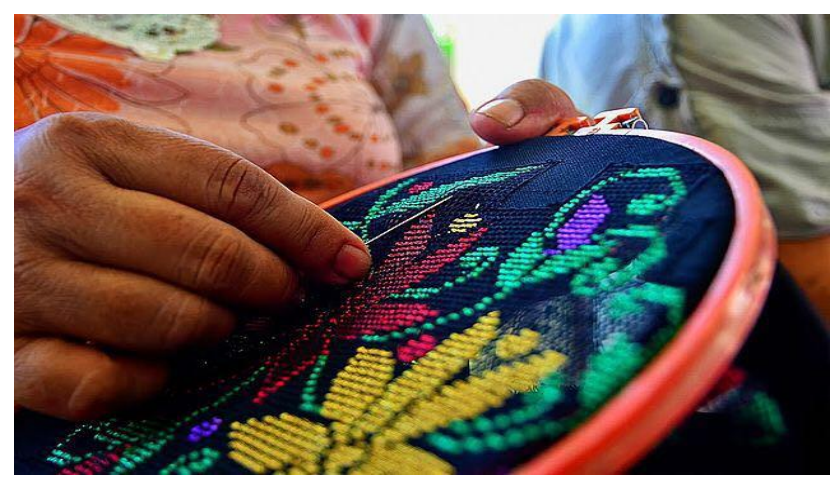

Gambar 2. Salah satu Proses Karawo

Produksi kain Karawo atau Karawo sempat mati suri. Tidak banyak perajin yang menekuni dunia ini karena kerumitan yang menyita banyak energi, waktu dan ketekunan. Oleh karena itu, pemerintah melakukan berbagai cara untuk membuat kerajinan ini dapat terus lestari dan semakin populer baik di dalam maupun di luar negeri. Salah satu cara yang dilakukan pemerintah adalah mengadakan festival Karawo yang telah digelar sejak pertama kalinya tanggal 17-18 Desember 2011. Festival yang akan terus digelar setahun sekali ini bertujuan untuk menarik minat masyarakat dalam mengenakan hasil industri produk Karawo sekaligus menguatkan ekonomi melalui pengembangan budaya daerah. 

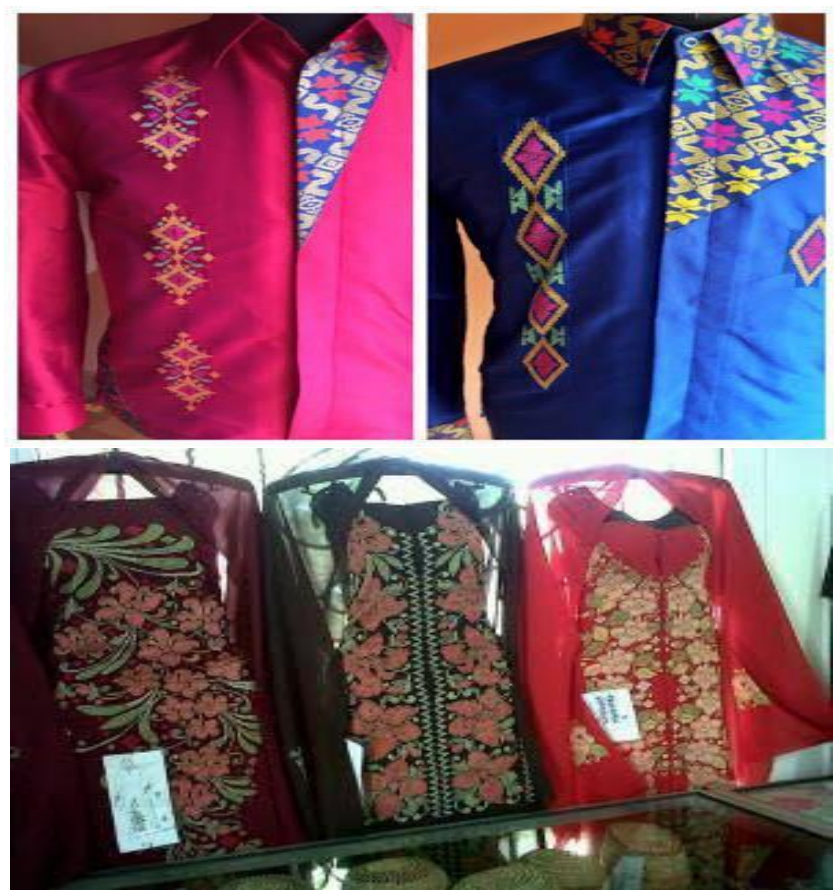

Gambar 3. Produk Karawo untuk Busana Pria dan Wanita

Industri adalah kegiatan ekonomi yang mengolah bahan mentah, bahan baku, barang setengah jadi atau barang jadi menjadi barang dengan nilai yang lebih tinggi lagi penggunaannya, termasuk kegiatan rancang bangun industri dan perekayasaan industri (Kartasapoetra, 2000). Industri kerajinan tangan sulaman kain Karawo merupakan salah satu produk original hasil karya masyarakat Gorontalo, yang selama ini menjadi khas dan populer berasal dari Gorontalo. Kerajinan ini telah dilakukan secara turun temurun di masyarakat Gorontalo yang banyak diminati bukan saja di wilayah Gorontalo tetapi juga diluar Gorontalo.

Karawo sebagai produk kerajinan kebanggaan masyarakat Gorontalo, diharapkan terus terpelihara di tingkat pengrajin untuk terus mengembangkan dan meningkatkan manajemen dan kualitas atas produk kerajinan. Sebagai produk asli unggulan daerah Gorontalo maka berbagai pihak telah mengambil peran dalam upaya melestarikan produk ini. Pemerintah provinsi Gorontalo dan enam daerah kabupaten/kota telah mewajibkan seluruh Aparatur Sipil Negara untuk menggunakan pakaian Karawo pada setiap hari Kamis. Hal itu pun diikuti oleh instansi vertikal lainnya, BUMN, swasta dan masyarakat pada umumnya. Disamping itu pula produk kain Karawo dijadikan sebagai oleh-oleh khas Gorontalo yang menjadi bagian dari pengembangan wisata, sehingga produk ini menjadi buruan baik wisatawan domestik maupun wisatawan asing yang pada akhirnya berdampak pada kesejahteraan pengrajin. Hal ini menjadi penting karena pengembangan wisata merupakan bagian yang tidak terpisahkan dengan upaya-upaya konservasi, pemberdayaan ekonomi lokal dan mendorong respek yang lebih tinggi terhadap perbedaan kultur atau budaya (Fandeli, 2000; Damanik \& Weber, 2006; Satria, 2009). 


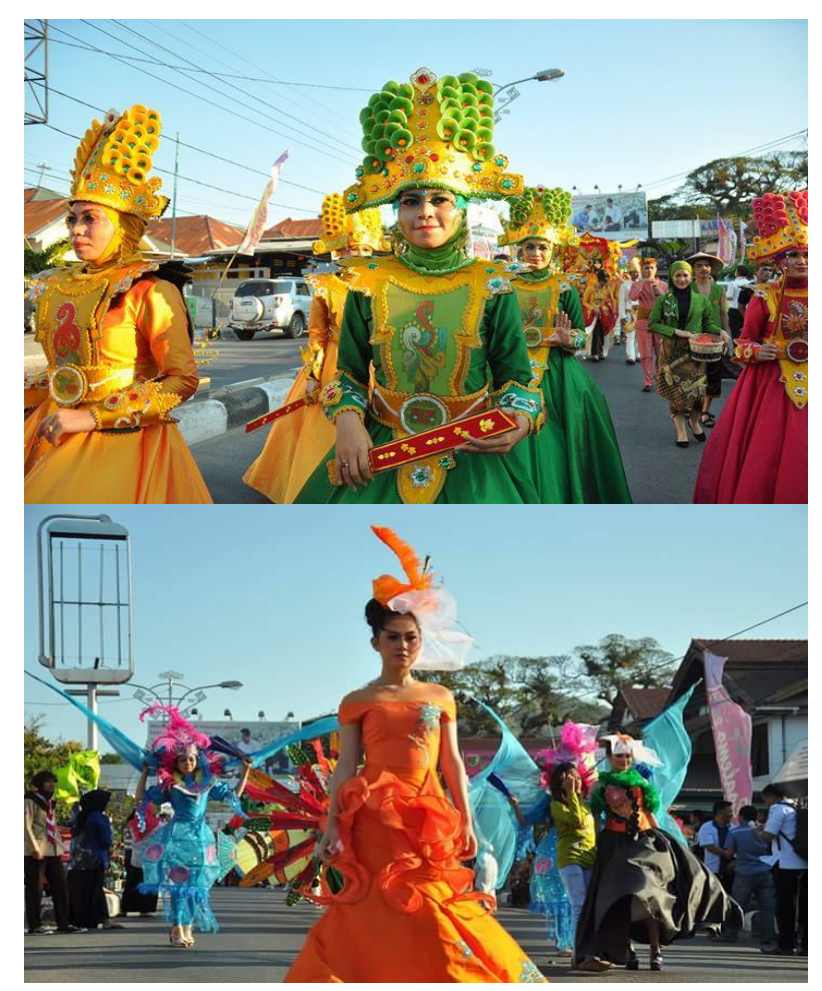

Gambar 4. Festival Karawo Gorontalo

Sinergi Pemeritah dan Perguruan Tinggi serta masyarakat sangat diperlukan dalam upaya Pemberdayaan untuk meningkatkan kesejahteraan (Sulila, 2016). Produk kerajinan Karawo terdapat di berbagai tempat di Gorontalo, salah satunya di desa Bongo Kecamatan Batudaa Pantai Kabupaten Gorontalo Provinsi Gorontalo. Dari beberapa usaha kecil sulaman Karawo di wilayah ini terdapat dua kelompok yang menarik perhatian tim untuk masuk dalam program pengembangan unggulan daerah, yaitu Kelompok usaha Sulaman Karawo Annisa dan Kelompok usaha Nirwana. Penetapan kedua kelompok ini dilatarbelakangi oleh beberapa alasan: 1) adanya kesungguhan dari kedua usaha kecil dimaksud dalam mempertahankan usaha walaupun dalam kondisi sulit, 2) produk sulaman Karawo yang belum dikembangkan, 3) masih kurangnya kapasitas manajemen dan mutu produk, 4) kesediaan dan keterbukaan untuk mengembangkan usaha kecil menjadi produk berstandar sesuai permintaan pasar.

Dalam upaya mempertahankan keberadaan produk asli Karawo dan pengembangan produk kerajinan khas Gorontalo dimaksud, dibutuhkan peran dari berbagai pihak, baik pemerintah, swasta, perguruan tinggi atau lembaga terkait lainnya. Dengan meningkatnya kemampuan kelompok sasaran dalam fokus penerapan metode penyiapan bahan baku, dapat menjamin kontinuitas produksi (Sulila, 2018). Sebagai lembaga tinggi yang syarat akan pengembangan ilmu pengetahuan dan teknologi maka mutlak dibutuhkan peran perguruan tinggi dalam transper keilmuan. Usulan program unggulan daerah sebagai salah satu bentuk kepedulian perguruan tinggi dalam mempertahankan dan mengembangkan produk asli daerah berdasarkan kearifan masyarakat lokal. Dengan adanya penerapan manajemen yang baik dalam suatu industri sangat menentukan keberhasilan dan keberlanjutan usaha (Octaviani, Narti, \& Nurwita, 2018). Namun demikian tidak maksimalnya praktek fungsi manajemen dan SDM pengembangan usaha kelompok yang berkelanjutan dan dibutuhkan bimbingan teknis aspek keuangan, produksi, pemasaran dan aspek penting lainnya (Dungga, Sulila, \& Aneta, 2018). Dalam 
konteks penerapan Iptek, permasalahan yang dihadapi kedua mitra ini sebenarnya tidak berbeda jauh. Oleh karena itu program untuk perbaikan kedua UKM ini pun berjalan bersamaan. Adapun masalah prioritas yang menjadi fokus pada kegiatan ini meliputi: 1) penerapan Iptek standarisasi ragam produksi sulaman kain Karawo oleh kelompok usaha masyarakat, 2) penerapan Iptek pemasaran ragam produk Karawo di khalayak lokal dan nasional serta internasional, 3) penerapan Iptek distribusi ragam produk Karawo ke tangan konsumen.

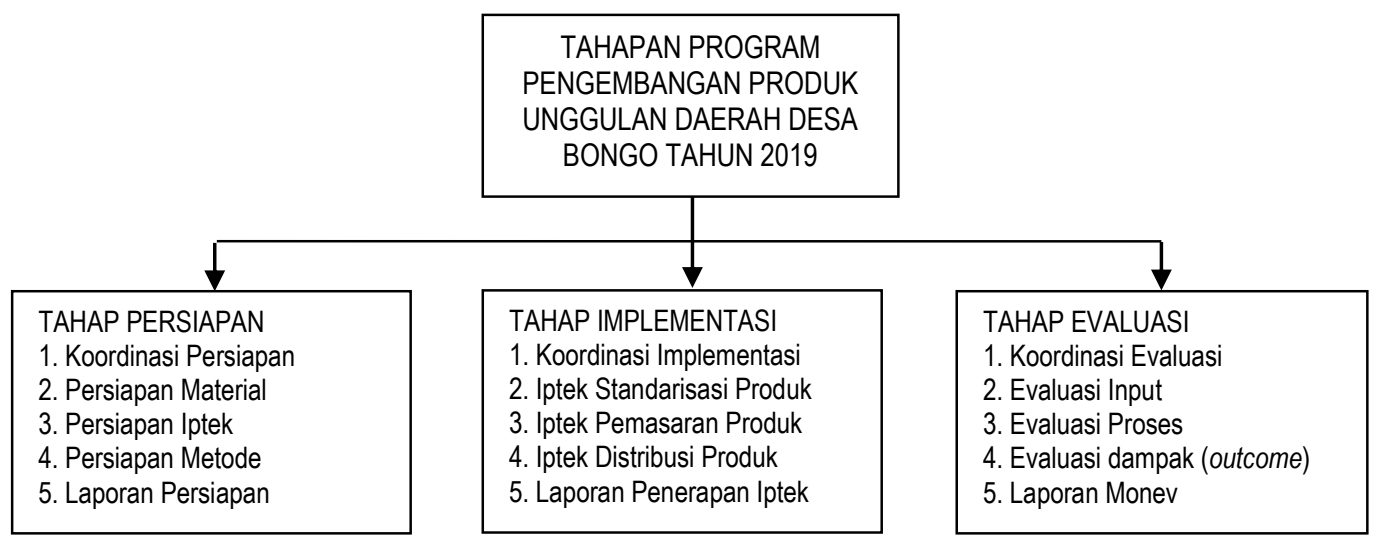

Gambar 5. Tahap Implementasi Program Pengembangan Produk Unggulan Daerah

\section{METODE PELAKSANAAN}

Dalam penetapan metode pelaksanaan dilakukan berdasarkan hasil identifikasi awal atas permasalahan di lapangan. Analisis data sebagai suatu proses yang merinci usaha formal untuk menemukan tema dan merumuskan ide sebagai yang disarankan oleh data, dan sebagai usaha untuk memberikan bantuan pada tema dan ide tersebut (Aries, 2010). Dalam upaya menghasilkan target kerja penyelesaian masalah prioritas mitra maka dibutuhkan pemilihan metode pelaksanaan yang tepat. Metode tersebut disesuaikan dengan program yang meliputi penerapan Iptek standarisasi produk, penerapan Iptek pemasaran dan penerapan Iptek distribusi produk. Lemahnya kemampuan manajemen ini mengakibatkan pengusaha kecil tidak mampu mengelola usahanya dengan baik (Kuncoro, 2006).

Secara rinci metode pelaksanaan untuk meningkatkan manajemen usaha dijelaskan sebagai berikut: 1) Produk. Metode efektif yang dilaksanakan meliputi: a) Menyiapkan pola baru untuk keenam jenis produk Karawo, b) menyiapkan desain dan motif baru Karawo pada keenam produk, yang meliputi Karawo motif walimah, ikan, pohon kelapa dan motif masjid, c) mengaplikasikan keenam motif khas unggulan dimaksud pada keenam jenis produk Karawo, d) mengkombinasikan enam jenis produk Karawo dengan produk batik, e) menyiapkan produk Karawo berdasarkan usia pengguna. 2) Pemasaran. Metode efektif yang dilaksanakan meliputi: a) Tim pengabdi dan pengurus UKM melakukan survey pasar di 6 daerah kabupaten/kota, b) membuat peta wilayah pemasaran sesuai permintaan jenis produk unggulan yang dihasilkan UKM, c) melaksanakan pemasaran pada wilayah sesuai dengan peta yang telah ditentukan. d) memperkenalkan dan memasarkan Karawo motif walimah, motif ikan, motif pohon kelapa dan motif masjid, sebagai produk Karawo unggulan yang hanya ada di desa wisata religius Bongo. 3) Distribusi. Metode efektif yang dilaksanakan meliputi: a) menyiapkan personil yang akan bertugas mendistribusikan produk pada enam kabupaten kota, b) 
menyiapkan fasilitas mobil untuk distribusi keenam produk pada enam daerah kabupate/kota se Provinsi Gorontalo, c) mendistribusikan produk pada outlet-outlet yang telah bekerjasama dengan UKM.

\section{HASIL DAN PEMBAHASAN}

Berdasarkan pendahuluan dan penetapan metode pelaksanaan maka implementasi program secara sistematis dan komprehensif mutlak dibutuhkan dalam pemberdayaan masyarakat. Menurut Mubarak (2010) pemberdayaan masyarakat dapat diartikan sebagai upaya untuk memulihkan atau meningkatkan kemampuan suatu komunitas untuk mampu berbuat sesuai dengan harkat dan martabat mereka dalam melaksanakan hakhak dan tanggungjawab selaku anggota masyarakat.

\section{Penerapan Iptek Standarisasi Produk}

Hal penting dalam dunia bisnis adalah menghasilkan produk untuk dijual. Produk Karawo sejak dulu dihasilkan dengan model yang cenderung monoton tanpa sentuhan pengembangan sama sekali. Hal tersebut dapat menyebabkan desain Karawo bagi konsumen menjadi jenuh. Oleh karena itu solusi konkrit yang ditargetkan adalah melakukan inovasi untuk pengembangan produk dalam bentuk sebagai berikut: 1) kombinasi antara Karawo dengan batik, 2) penggunaan sulaman Karawo pada kain sutera, 3) penggunaan motif baru sesuai permintaan pasar, 4) penggunaan sulaman Karawo pada corak baru, 5) berbagai desain baru untuk meraih minat konsumen menggunakan kain rawang moderen. 6) menghasilkan produk Karawo untuk anak-anak, remaja, dewasa, Karawo adat, santai dan Karawo resmi, 7) membuat Karawo motif walimah, motif ikan, motif pohon kelapa dan motif masjid sebagai produk Karawo unggulan dengan ciri khas yang unik yang hanya didapatkan di desa wisata religius Bongo.

Tabel 1. Standarisasi dan Pengembangan Produk Karawo Unggulan

\begin{tabular}{llll}
\hline No & Kegiatan & Hasil & Keterangan \\
\hline 1 & Bimbingan teknis & Menghasilkan motif & Kerjasama dengan Dinas \\
& $\begin{array}{l}\text { desain dan motif } \\
\text { Karawo pada 6 } \\
\text { (enam) produk }\end{array}$ & $\begin{array}{l}\text { walimah, ikan, pohon kelapa } \\
\text { dan motif masjid, sebagai ciri } \\
\text { khas produk terbaru pada } \\
\text { enam jenis produk }\end{array}$ & $\begin{array}{l}\text { Perindagkop Kabupaten } \\
\text { Nasional Daerah Gorontalo } \\
\text { dan Mitra pembeli produk }\end{array}$ \\
\hline 2 & Mengembangkan & Terdapat ciri khas terbaru & Kerjasama dengan Dinas \\
& kemasan produk & dalam kemasan Karawo & Perindagkop Kabupaten \\
& dengan ciri khas & Gorontalo untuk enam jenis & Gorontalo, Dewan Kerajinan \\
& Karawo Gorontalo & produk & Nasional Daerah Gorontalo \\
& Merinci spesifikasi & Terdapat spesifikasi Karawo & Kerjasama dengan Dinas \\
& produk pada & pada enam jenis produk & Perindagkop Kabupaten \\
& kemasan & UMKM & Gorontalo, Dewan Kerajinan \\
& & & Nasional Daerah Gorontalo \\
& & & dan Mitra pembeli produk \\
\hline 4 & Mengembangkan & Terdapat produk Karawo & Kerjasama dengan Dinas \\
& Karawo sesuai & sesuai sasaran/kebutuhan & Perindagkop Kabupaten \\
& kebutuhan & pengguna (anak-anak, & Gorontalo, Dewan Kerajinan \\
& pengguna & remaja, dewasa, santai dan & Nasional Daerah Gorontalo \\
& formal) & dan Mitra pembeli produk \\
\hline
\end{tabular}


Sumber: Hasil analisis lapangan tahun 2019

Mewujudkan inovasi dan pengembangan produk Karawo melalui motif yang unggul dengan ciri khas desa wisata religius yang sedapat mungkin mengikuti kebutuhan dan permintaan pasar di Provinsi Gorontalo. Secara rinci inovasi dan pengembangan produk dilakukan melalui beberapa kegiatan dapat dilihat sebagaimana pada Tabel 1.

Berdasarkan penjelasan di atas, maka penerapan Iptek standarisasi produk menghasilkan luaran ada perbaikan nyata terhadap kualitas produk dan inovasi terhadap 6 jenis produk Karawo dalam bentuk kombinasi kain Karawo dengan jenis kain lain dan menampilkan ciri khas Karawo desa wisata religius Bongo.

\section{Penerapan Iptek Pemasaran}

Aspek penting lain dalam usaha adalah pasar. Solusi yang ditawarkan untuk UMKM adalah melakukan pemetaan pasar secara ilmiah, nyata dan terukur melalui: 1) melakukan survey pasar pada 6 wilayah Kabupaten/Kota se Provinsi Gorontalo, 2) perluasan pangsa pasar melalui penawaran produk terbaru hasil inovasi UMKM, 3) melakukan penetapan harga pasar secara rasional yang menguntungkan UMKM dan konsumen se provinsi Gorontalo, 4) menetapkan konsumen strategis pada 6 kabupaten kota se provinsi Gorontalo, 5) membuat kontrak kerja bisnis dengan beberapa toko/outlet Karawo di 6 kabupaten/kota, 6) melaksanakan pemasaran secara online, 7) melihat dan mengestimasi pasar diluar provinsi Gorontalo, yakni Sulawesi Utara, Tengah, Tenggara, Barat dan Sulawesi Selatan. Penerapan Iptek yang ditawarkan dalam pemasaran dan target penjualan dapat dirinci pada Tabel 2.

Tabel 2. Pemasaran Produk Karawo Unggulan

\begin{tabular}{llll}
\hline No & Metode pemasaran & Sasaran & Target \\
\hline 1 & $\begin{array}{l}\text { Pemasaran melalui } \\
\text { mitra }\end{array}$ & 4 Outlet di Kota Gorontalo & $\begin{array}{l}\text { Semua Jenis Produk } \\
\text { Karawo }\end{array}$ \\
\hline 2 & $\begin{array}{l}\text { Pemasaran langsung } \\
\text { oleh UMKM }\end{array}$ & $\begin{array}{l}\text { Pegawai/Karyawan se } \\
\text { Provinsi Gorontalo }\end{array}$ & $\begin{array}{l}\text { SKPD } \\
\text { Kab/Kota/Prov/Swasta }\end{array}$ \\
\hline 3 & Pemasaran online & $\begin{array}{l}\text { Semua } \\
\text { kalangan/Daerah/Nasional } \\
\text { dan internasional }\end{array}$ & Semua Produk Karawo \\
& & $\begin{array}{l}\text { Pengunjung stand Even } \\
\text { Pameran UMKM Karawo }\end{array}$ & $\begin{array}{l}\text { Even pameran Kab/Kota } \\
\text { dan Provinsi }\end{array}$ \\
\hline 4 & Pemasaran melalui \\
& pameran & Kegiatan Carnaval Karawo & $\begin{array}{l}\text { Kab/Kota se Provinsi } \\
\text { Gorontalo }\end{array}$ \\
\hline 5 & $\begin{array}{l}\text { Pemasaran melalui } \\
\text { Festival Karawo }\end{array}$ & & \\
\hline
\end{tabular}

Sumber: Hasil analisis lapangan tahun 2019

Berdasarkan penjelasan solusi di atas, maka penerapan Iptek pemasaran menghasilkan luaran penetapan tujuan pemasaran yang jelas, harga yang pasar yang pasti, konsumen strategis dan kontrak kerja yang saling menguntungkan, pemasaran online serta tujuan daerah pemasaran yang lebih luas.

\section{Penerapan Iptek Distribusi Produk}

Pada aspek penerapan Iptek distribusi produk hingga ke tangan konsumen, solusi yang ditawarkan melalui distribusi produk berdasarkan kebutuhan pasar yang telah ditetapkan pada aspek pemasaran. Selanjutnya ditentukan pula segementasi pemasaran, yaitu pemasaran produk Karawo berdasarkan daerah, berdasarkan usia, berdasarkan 
jumlah kebutuhan dan sebagainya. Selanjutnya distribusi dilakukan dengan menggunakan transportasi untuk pasar dalam Provinsi Gorontalo, dan menggunakan ekspedisi pengiriman untuk luar Provinsi Gorontalo. Bentuk kegiatan yang dilakukan untuk memperbaiki distribusi dapat dilihat pada Tabel 3.

Tabel 3. Distribusi Produk Karawo Unggulan

\begin{tabular}{llll}
\hline No & Kegiatan & Sasaran & Hasil \\
\hline 1 & $\begin{array}{l}\text { Pemetaan konsumen } \\
\text { berdasarkan sasaran } \\
\text { penjualan produk Karawo } \\
\text { biasa dan unggulan }\end{array}$ & UKM Pengrajin & $\begin{array}{l}\text { Adanya peta sasaran } \\
\text { konsumen untuk penjualan } \\
\text { produk Karawo biasa dan } \\
\text { Karawo unggulan }\end{array}$ \\
\hline 2 & $\begin{array}{l}\text { Pemetaan pasar berdasarkan } \\
\text { kebutuhan produk Karawo di } \\
\text { masing-masing daerah }\end{array}$ & UKM Pengrajin & $\begin{array}{l}\text { Adanya peta konsumen } \\
\text { sesuai kebutuhan produk di } \\
\text { daerah }\end{array}$ \\
\hline 3 & Penetapan metode distribusi & UKM Pengrajin & $\begin{array}{l}\text { Terdistribusinya dengan cara } \\
\text { efektif enam jenis produk }\end{array}$ \\
& $\begin{array}{l}\text { yang efektif melalui } \\
\text { pemasaran outlet kemitraan } \\
\text { dan pemasaran on line }\end{array}$ & Karawo & $\begin{array}{l}\text { Karawo biasa dan unggulan } \\
\text { untuk memenuhi kebutuhan } \\
\text { pasar di Provinsi Goronalo }\end{array}$ \\
\hline 4 & Rekonstruksi kontrak bisnis & & UKM Pengrajin \\
& dengan mitra & Adanya kontrak kerja yang \\
penampung/pembeli produk & Karawo & jelas dan Penguatan posisi \\
& Kawaw yang menguntungkan \\
& & & $\begin{array}{l}\text { kedua belah pihak, baik } \\
\text { UMKM maupun mitra usaha }\end{array}$ \\
\hline 5 & Menyiapkan fasilitas & UKM Pengrajin & $\begin{array}{l}\text { Tersedianya fasilitas } \\
\text { transportasi untuk distribusi } \\
\text { produk pada konsumen }\end{array}$ \\
\hline & transportasi distribusi produk & Karawo & \\
\hline
\end{tabular}

Sumber: Hasil analisis lapangan tahun 2019

Berdasarkan penjelasan di atas, maka penerapan Iptek distribusi produk menghasilkan luaran, yaitu memberikan kepastian sasaran pasar yang jelas berdasarkan segmentasi pasar, mekanisme/prosedur pengiriman yang jelas baik dalam provinsi maupun luar provinsi.

Manajemen strategis merupakan suatu rencana yang disusun dan dikelola dengan memperhitungkan berbagai sisi dengan tujuan agar pengaruh rencana memberikan dampak positif bagi organisasi dalam jangka panjang (Fahmi, 2015). Oleh karena itu dalam upaya keberlanjutan program maka dibutuhkan evaluasi program. Evaluasi pelaksanaan program difokuskan untuk: 1) melakukan pengecekan untuk memastikan proses yang dilaksanakan dalam tiga tahun terakhir sesuai dengan standarisasi yang telah ditetapkan bersama dengan tim PPPUD. Dengan melaksanakan proses sesuai standar maka jaminan kualitas dapat diwujudkan pada keenam jenis produk Karawo, termasuk motif Karawo unggulan sebagai ciri khas, 2) melakukan pengecekan untuk memastikan jenis, jumlah spesifikasi dan mutu produk Karawo telah sesuai dengan rencana produksi baik periode bulanan maupun dalam satu tahun, 3) melakukan pengecekan langsung terhadap hasil proses pemasaran dalam satu periode, apakah metode pemasaran di outlet-outlet telah berjalan sesuai rencana, apakah pemasaran melalui online dapat diakses oleh publik, apakah teknik pemasaran yang digunakan efektif mencapai target penjualan. 4) melakukan pengecekan langsung untuk memastikan distribusi produk di berbagai outlet, diberbai daerah ataupun pengiriman pesanan produk Karawo secara online berjalan dengan baik. Apabila terdapat kendala dalam prakteknya maka tim 
pelaksana PPPUD dan mitra UKM segera melakukan kajian untuk mencarikan solusi perbaikan yang nyata, komprehensif dan efektif sehingga semua proses berjalan sesuai rencana.

\section{SIMPULAN}

Berdasarkan hasil penerapan ilmu pengetahuan dan teknologi pada ketiga program prioritas maka terdapat beberapa kesimpulan yang dapat dirinci sebagai berikut: 1) Penerapan Iptek standarisasi ragam produk Karawo mampu memberikan batasan kualitas produk sesuai dengan kebutuhan pasar, harga dan pengguna produk. 2) Penerapan Iptek pemasaran melalui penggunaan media sosial mampu meningkatkan permintaan pasar ragam produk Karawo di tingkat lokal dan nasional. 3) Penerapan Iptek distribusi ragam produk ke tangan konsumen yang dilakukan melalui kerjasama media dan transportasi online mampu mendistribusikan ragam produk ke tangan konsumen khususnya untuk pasar lokal di wilayah enam kabupaten kota se-Provinsi Gorontalo.

\section{Ucapan Terima kasih}

Dalam upaya mencapai keberhasilan penerapan iptek sesuai target kerja, tim pelaksana PPPUD dibantu berbagai pihak. Oleh karena itu ucapan terimakasih disampaikan kepada: 1) Direktorat Riset dan Pengabdian Masyarakat, 2) Pemerintah daerah Kabupaten Gorontalo, 3) LPPM Universitas Negeri Gorontalo, 4) Kelompok masyarakat, tim pelaksana dan mahasiswa, 5) Semua pihak yang telah membantu suksesnya kegiatan pengabdian pada masyarakat ini.

\section{REFERENSI}

Aries, E. F. (2010). Design action research. Malang: Aditya Media Publishing

Damanik, J., \& Weber, H. F. (2006). Perencanaan ekowisata: Dari teori ke aplikasi. Yogyakarta: Puspar UGM dan Andi.

Dungga, W. A., Sulila, I., \& Aneta, Y. (2018). Pentingnya aspek hukum pelestarian danau Limboto dan pemanfaatan eceng gondok sebagai produk kerajinan tangan khas masyarakat Desa Buhu Kabupaten Gorontalo. Jurnal Pengabdian Kepada Masyarakat, 24(2), 617-622.

Fahmi, I. (2015). Manajemen Strategis. Teori dan Aplikasi. Bandung: Alfabeta.

Fandeli, C. (2000). Pengertian dan konsep dasar ekowisata. Yogyakarta: Fakultas Kehutanan UGM.

Kartasapoetra, G. (2000). Makro ekonomi; Edisi Kedua. Jakarta: Raja Grafindo Persada.

Kuncoro, M. (2006). Usaha Kecil di Indonesia: Profil. Masalah dan strategi pemberdayaan. Jurnal Usaha Kecil Indonesia. 1-19 
Mubarak, Z. (2010). Evaluasi pemberdayaan masyarakat dari proses pengembangan kapasitas program PNPM Mandiri Perkotaan di Desa Sastrodirjan Kabupaten Lamongan (Unpublished master's thesis). Universitas Diponegoro, Semarang, Indonesia.

Octaviani, V., Narti, S., \& Nurwita, S. (2018). Peningkatan sumber daya masyarakat desa dalam binaan pusat kegiatan belajar masyarakat (PKBM). Jurnal Pengabdian Pada Masyarakat, 3(2), 117-124.

Satria, D. (2009). Strategi pengembangan ekowisata berbasis ekonomi lokal dalam rangka program pengentasan kemiskinan di wilayah Kabupaten Malang. Journal of Indonesian Applied Economics, 3(1), 37-47.

Sulila, I. (2016). Pemberdayaan masyarakat melalui peningkatan kapasitas manajemen dan mutu produk pada kelompok kerajinan Karawo di Desa Bongo Kabupaten Gorontalo. Jurnal Pengabdian Kepada Masyarakat, 22(3), 96-102.

Sulila, I. (2018). Penguatan kapasitas tata kelola keuangan dan produksi bagi kelompok masyarakat pengrajin karawo Desa Wisata Religius Bongo Kabupaten Gorontalo. Jurnal Pengabdian Kepada Masyarakat, 24(2), 610-616. 